\title{
The use of radio-collars for monitoring wildlife diseases: a case study from Iberian ibex affected by Sarcoptes scabiei in Sierra Nevada, Spain
}

Samer Alasaad ${ }^{1{ }^{*}+}$, José E Granados ${ }^{2 \dagger}$, Paulino Fandos ${ }^{3+}$, Francisco-Javier Cano-Manuel ${ }^{2 \dagger}$, Ramón C Soriguer ${ }^{1 \dagger}$ and Jesús M Pérez ${ }^{4 \dagger}$

\begin{abstract}
Background: Wildlife radio tracking has gained popularity during the recent past. Ecologists and conservationists use radio-collars for different purposes: animal movement monitoring, home range, productivity, population estimation, behaviour, habitat use, survival, and predator-prey interaction, among others. The aim of our present study is to highlight the application of radio-collars for wildlife diseases monitoring. The spread of wildlife diseases and the efficacy of management actions for controlling them propose serious challenges for ecologists and conservationists, since it is difficult to re-capture (or simply observe) the same animal in pre-determined temporal interval, but such difficulty is overcome by the use of gps-gsm radio collars.
\end{abstract}

Methods: In the present study we report, for the first time to our knowledge, the use of radio-collars in the monitoring of Iberian ibex affected by Sarcoptes scabiei in Sierra Nevada mountain range, Spain. Twenty-five moderate or slightly mangy animals were radio-collared between 2006 and 2013.

Results: The radio-collars allowed us to confirm the presence of resistance to $S$. scabiei within Iberian ibex population. Twenty (80\%) of the collared animals recovered totally from mange, while the disease progressed in the other five Iberian ibex (20\% of the collared animals) and the animals died. The average estimated recovery time of the resistant animals was $245 \pm 277$ days, and the estimated average survival time of the non-resistant Iberian ibex was $121 \pm 71$ days. Non-resistant animals survived at least 100 days, while all of them died with less than 200 days. Sixty per cent of the resistant animals were recovered with less than 200 days.

Conclusions: We report, for the first time, the successful use of radio collars for wildlife diseases monitoring using Iberian ibex/S. scabiei as a model. By using radio collars we documented that most of the Sarcoptes-infected Iberian ibex are resistant to this disease, and we estimated the average time for Iberian ibex recovering from mange infection and the average survival time of the non-resistant ones. We expect wider use of radio-collars for wild animals diseases monitoring, affected/not-affected animals interaction, and treatment efficacy, among others.

Keywords: GPS-GSM-radio collars, Capra pyrenaica, Sarcoptic mange, Disease control

\footnotetext{
* Correspondence: sameralasaad@hotmail.com

${ }^{\dagger}$ Equal contributors

'Estación Biológica de Doñana, Consejo Superior de Investigaciones

Científicas (CSIC), Avda. AméricoVespucio s/n, 41092, Sevilla, Spain

Full list of author information is available at the end of the article
} 


\section{Background}

The development of radio-telemetry and its replacement, nowadays, by Global Positioning System (GPS)-based research techniques, has revolutionized wildlife research by gaining additional insight into the secretive lives of animal movements and ecology $[1,2]$.

Detailed ecological and conservation questions were revealed by the application of this technological approach (Radio- telemetry and GPS collar technology) on wildlife research: 1-animal movement patterns on large scale (migration or dispersal) and smaller scale (spatial and temporal travel corridors); 2-behavioural studies (daily or seasonal activity patterns of individual animals); 3-home ranges of individual animals (quantitative estimates of area used in time and space); 4-habitat use and management; 5survival studies (differentiate between emigration and mortality); 6-reproductive parameters (litter size, interbirth interval, adult survival and cub survival, and causes of mortality); 7-population size (using mark-recapture methods) and bio-telemetry, among others [3-7]. Such questions could not have been answered using other research approaches, such as land or aerial tracking, scat analysis, DNA analysis, detector dogs, or camera trapping [8-10].

Despite the pivotal advantages of the radio-collars, they were not applied, to the best of our knowledge, on wildlife disease monitoring.

Sarcoptes scabiei affects humans and a wide range of mammalian hosts worldwide $[11,12]$. It is an opportunistic parasite [13], incomprehensibly emerging and re-emerging with neglected navigating web, through which $S$. scabiei move from one to another host [14].

S. scabiei entails significant mortality in both wild and domestic animals, with considerable economic losses [15-17], and ravages in human populations [18].

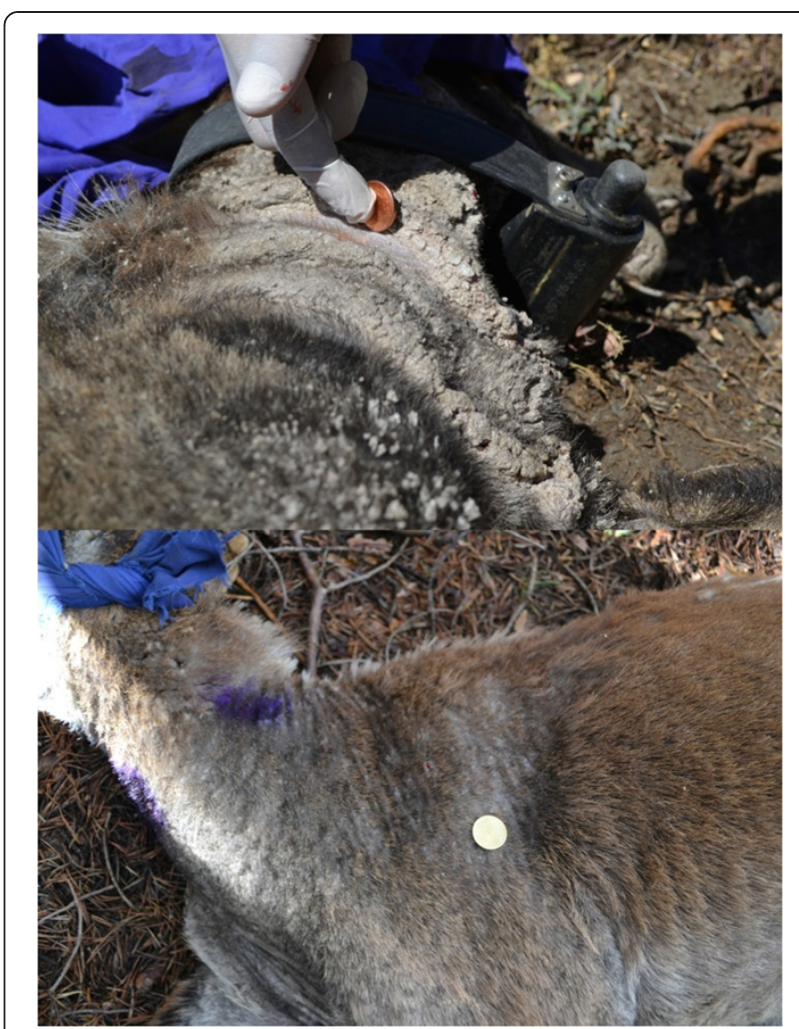

Figure 2 Photos showing the decrease of mange lesions and the recover of the normal skin and hair of one collared resistant Iberian ibex (up = before, down = after), Sierra Nevada, Spain.

Iberian ibex (Capra pyrenaica) population from Sierra Nevada mountain range in Spain is one of the most affected by S. scabiei [19-21]. Nonetheless, there are no clear studies about (i) the possible resistance of Iberian ibex to S. scabiei, (ii) the average survival time of the non-resistant animals,

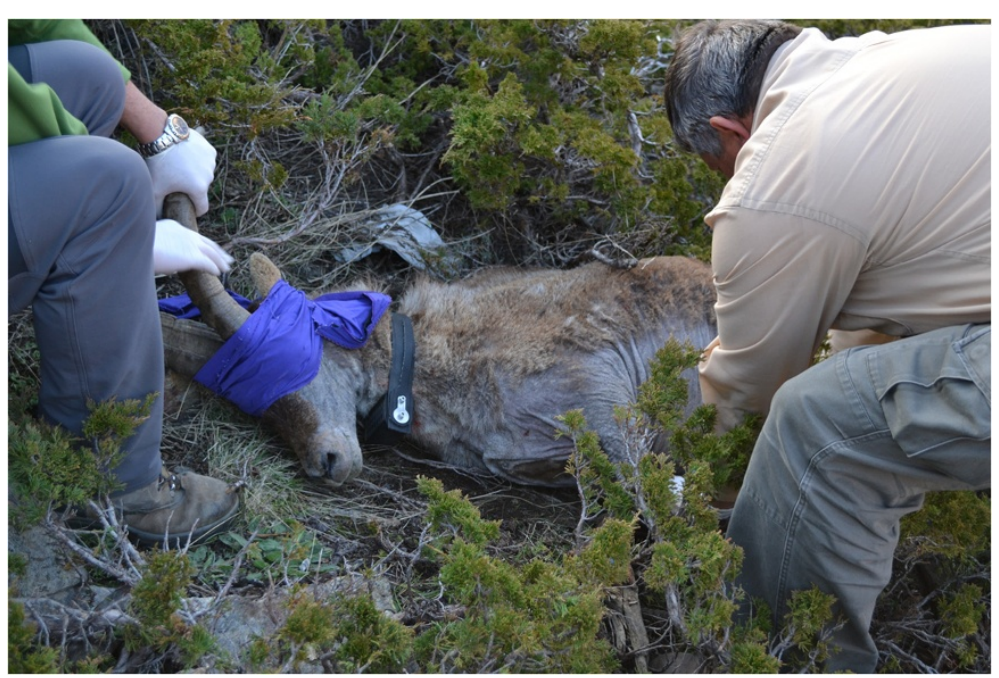

Figure 1 Mangy Iberian ibex capturing and gps-radio collaring, Sierra Nevada, Spain. 


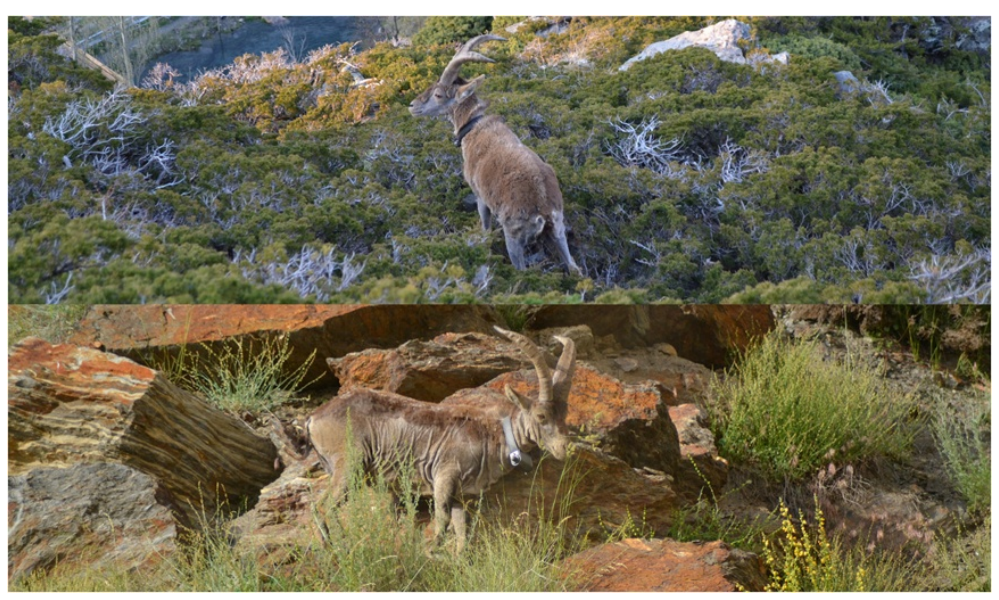

Figure 3 Photos showing the increase of mange lesions and the loss of hair of one collared non-resistant lberian ibex (up = before, down $=$ after), Sierra Nevada, Spain.

and (iii) the recovery time of the resistant ones, if any. Such aspects are almost impossible to approach by the direct observation of the affected animals, based on the limited access to different parts of Sierra Nevada because of the harsh climatology and territory of this mountain range and the absence of adequate roads. And hence the pivotal role of the gps-gsm radio collars, which allow localizing the marked animal at any time.

\section{Methods}

Animals capturing, radio collaring, monitoring and mange infection evaluation

Between 06/02/2006 and 10/06/2013, 25 mangy Iberian ibex (ranged between 3-9 year old) were immobilized by darting using a mixture of xylazine $(3 \mathrm{mg} / \mathrm{Kg})$ and ketamine $(3 \mathrm{mg} / \mathrm{Kg})$. Iberian ibex were collared with gps + gsm collars (Microsensory, Córdoba, Spain, and Vectronic Aerospace, Germany) (Figure 1). The movement of each

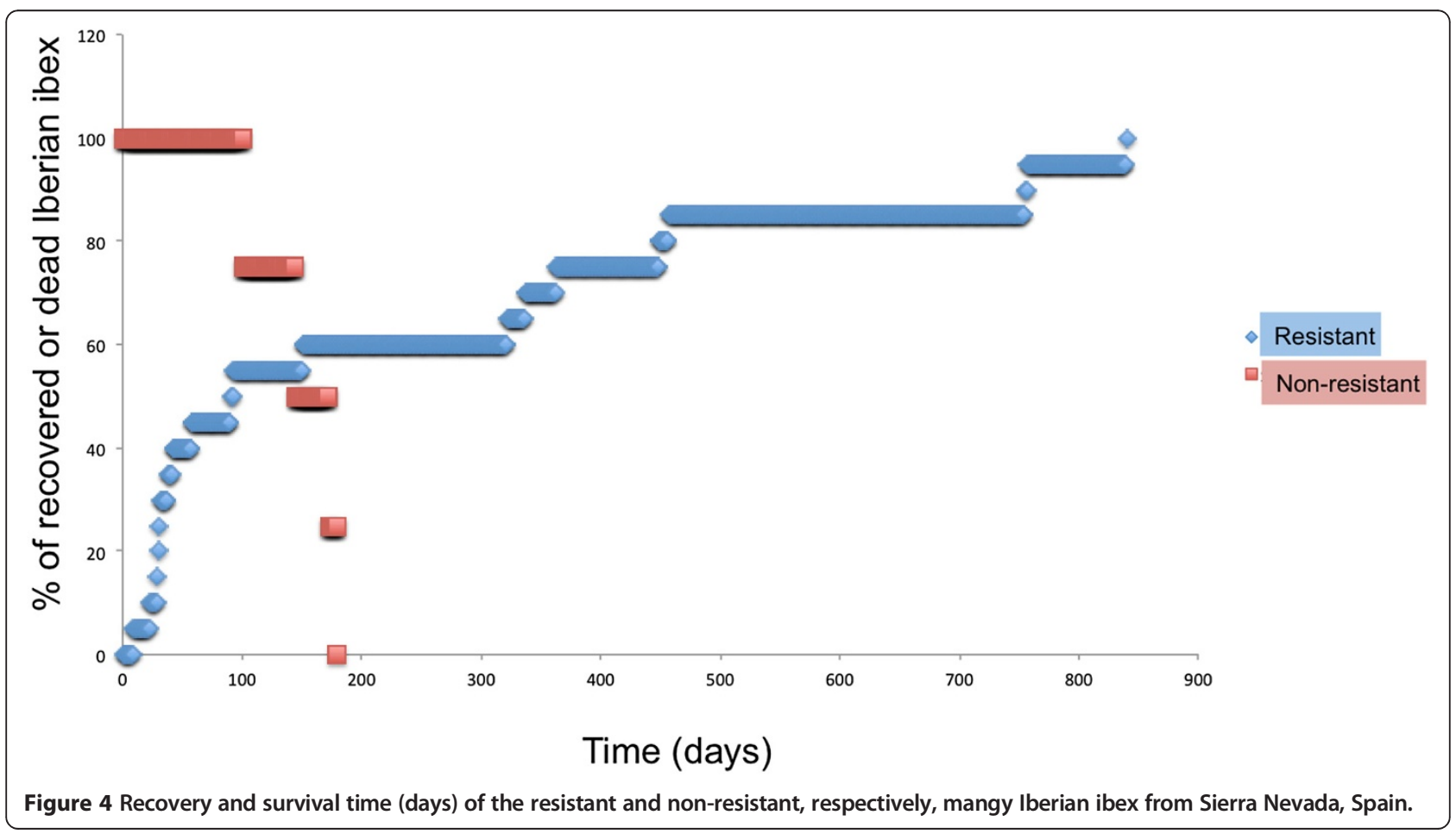


radio-collared animal was followed online using the webpage of the fabricant (www.wildgps.com). This webpage permits following the real-time movement of the animals, being updated every 3 hours. This allowed us easily localize the collared animals and hence the observation of the development of mange lesions.

The range estimated, once capturing the mangy Iberian ibex, visually (or by using binoculars or telescope when they observed the animal from far distance) the surface area of skin with sarcoptic lesions and animals were assigned to a mange field category on the basis of the area affected. The collared animals were moderately or slightly affected by mange, with less than $50 \%$ of the animal skin apparently affected. This category corresponds to less than $1324 \pm 551 \mathrm{mite} / \mathrm{cm}^{2}$ of the affected animal skin [22].

\section{Ethics}

This study complies the Spanish and the Andalusian laws regarding bioethics and animal welfare. Sierra Nevada National Park approved this study.

\section{Results and discussion}

Mange infections in 20 (80\% of the total) Iberian ibex were self-limited and the damaged skin surface decreased progressively, recovering new hair (Figure 2). The average time for total recovery was $245 \pm 277$ days. Meanwhile, other five (20\% of the total) Iberian ibex showed significant increase of mange infections by the amplification of the damaged skin, until animal death (Figure 3). The average survival time was $121 \pm 71$ days, longer than that described by León-Vizcaíno et al. [23] in Cazorla, Segura and Las Villas Mountains. Non-resistant animals survived at least 100 days, while all of them were dead in less than 200 days. Sixty per cent of the resistant animals were recovered with less than 200 days (Figure 4).

This is the first use of radio- collars for wildlife diseases monitoring, which allowed us to detect the presence of resistant free-ranging Iberian ibex in Sierra Nevada, and to estimate the recovery time, together with the survival time of the non-resistant ones. These results, with the cautions regarding the low sampling size, are of pivotal interest for the future conservation and management of the Iberian ibex in Spain, and could be used as a model for the world monitoring and management of the affected wild animal species. These results support the policy of Sierra Nevada National Park authorities, who remove only the highly or severly mangy Iberian ibex (with more than $50 \%$ of the animal skin is apparently affected), but not the moderately or slightly affected (with less than $50 \%$ of the animal skin is apparently affected).

The radio- collars could be of great help for wildlife diseases treatment. In the case of S. scabiei, affected animals usually need 2-3 doses of drug (such as ivermectin) with a temporal interval of 2-4 weeks, to guarantee efficient treatment. However, this is impracticable with wild animals, due to climatological, territorial and logistical factors, especially with the elusive species [24]. And hence the radio-collars could be of great help, allowing localizing the animals under treatment whenever is necessary for repeated treatment purpose, or just to observe the efficacy and results of the previous treatment.

Sarcoptes is mainly transmitted by host-to-host direct contact, and hence better understanding of the interaction between affected and not-affected individuals is of pivotal interest to clarify the epidemiology of this disease [14], which could be achieved by using radio collars.

\section{Conclusions}

In the present study we report, for the first time, the successful use of radio collars for wildlife diseases monitoring using Iberian ibex/S. scabiei as a model. By using radio collars we documented that most of the Sarcoptes-infected Iberian ibex are resistant to this disease, and we estimated the average time for Iberian ibex recovering from mange infection and the average survival time of the nonresistant ones. We expect wider use of radio-collars for wild animals diseases monitoring, affected/not-affected animals interaction, and treatment efficacy, among others.

\section{Competing interests}

The authors declared that they have no competing interests.

\section{Authors' contributions}

JEG, PF, RCS, SA and JMP conceived and designed the experiments. JEG, PF FJCM, RCS and JMP performed the fieldwork experiments. Manuscript was analysed, discussed and written by all co-authors. All authors read and approved the final version of the manuscript.

\section{Acknowledgements}

Thanks are due to Apolo Sánchez Lao, José López Pérez, Isidro Puga González, Elías Martínez Ortíz, Manuela Cárdenas Fernández, Francisco Casado Felipe, Antonio Rodríguez Dueñas and Antonio Rodríguez Huete for their assistance in fieldwork. The research was supported by the projects 173/2009/M/00 and 861/ 11/M/00 (CMA, Andalusian Government), CGL2004-03171 and CGL2012-40043C02-01 (MEC, Spanish Goverment), RTA 2009-00114-00-00 (INIA), RNM-6400, and Proyecto de Excelencia (Junta de Andalucia, Spain), together with Juan de la Cierva grant.

\section{Author details}

${ }^{1}$ Estación Biológica de Doñana, Consejo Superior de Investigaciones Científicas (CSIC), Avda. AméricoVespucio s/n, 41092, Sevilla, Spain. ${ }^{2}$ Espacio Natural de Sierra Nevada, Carretera Antigua de Sierra Nevada, km 7, E-18071, Pinos Genil, Granada, Spain. ${ }^{3}$ Agencia de Medio Ambiente y del Agua, Consejería de Medio Ambiente, Sevillam, Spain. ${ }^{4}$ Departamento de Biología Animal, Biología Vegetal y Ecología, Universidad de Jaén, Campus Las Lagunillas, s/n, E-23071, Jaén, Spain.

Received: 10 July 2013 Accepted: 20 August 2013

Published: 22 August 2013

\section{References}

1. Craighead FC, Craighead JJ: Tracking grizzly bears. BioScience 1965, 15:88-92.

2. Craighead JJ, Sumner JS, Mitchell JA: The Grizzly Bears of Yellowstone: Their Ecology in the Yellowstone Ecosystem, 1959-1992. Washington, DC: Island Press; 1995. 
3. Samuel MD, Fuller MR: Wildlife radiotelemetry. In Research and Management Techniques for Wildlife and Habitats. 5th edition. Edited by Bookhout TA. Bethesda, MD: The Wildlife Society; 1994:370-418.

4. Cagnacci F, Boitani L, Powell RA, Boyce MS: Animal ecology meets GPSbased radiotelemetry: a perfect storm of opportunities and challenges. Phil Trans R Soc B 2010, 365:2157-2162.

5. Tomkiewicz SM, Fuller MR, Kie JG, Bates KK: Global positioning system and associated technologies in animal behaviour and ecological research. Phil Trans R Soc B 2010, 365:2163-2176.

6. Miller CS, Hebblewhite M, Goodrich JM, Miquelle DG: Review of research methodologies for tigers: telemetry. Integr Zool 2010, 5:378-389.

7. Millspaugh JJ, Kesler DC, Kays RW, Gitzen RA, Schulz JH, Rota CT, Bodinof CM, Belant $J$, Keller BJ: Wildlife radiotelemetry and remote monitoring. In The wildlife techniques manual. 7th edition. Edited by Silvy NJ. Baltimore: The John Hopkins University Press; 2012:258-283.

8. Alasaad S, Permunian R, Gakuya F, Mutinda M, Soriguer RC, Rossi L: Sarcoptic-mange detector dogs used to identify infected animals during outbreaks in wildlife. BMC Vet Res 2012, 8:e110.

9. Alasaad S, Sánchez A, García-Mudarra JL, Pérez JM, Marchal JA, Romero I, Garrido-García JA, Soriguer RC: Single-tube HotSHOT technique for the collection, preservation and PCR-ready DNA preparation of faecal samples: the threatened Cabrera's vole as a model. Eur J Wildl Res 2012, 58:345-350.

10. Alasaad S, Jowers MJ, Garrido-García JA, Wandeler P, Fickel J, Sánchez A, Soriguer RC: Non-invasive molecular and morphological evidences for a so far undiscovered population of snow vole in Southern Spain. Mitochondrial DNA 2013. In press.

11. Pence DB, Ueckermann E: Sarcoptic mange in wildlife. Rev Sci Tech OIE 2002, 21:385-398.

12. Alasaad S, Walton S, Rossi L, Bornstein S, Abu-Madi M, Soriguer RC, Fitzgerald S, Zhu XQ, Zimmermann W, Ugbomoiko US, Heukelbach J: Sarcoptes-World Molecular Network (Sarcoptes-WMN): integrating research on scabies. Int J Infect Dis 2011, 15:294-297.

13. Alasaad S, Ndeereh D, Rossi L, Bornstein S, Permunian R, Soriguer RC, Gakuya F: The opportunistic Sarcoptes scabiei: a new episode from giraffe in the drought-suffering Kenya. Vet Parasitol 2012, 185:359-363.

14. Alasaad S, Rossi L, Heukelbach J, Pérez JM, Hamarsheh O, Otiende M, Zhu $\mathrm{XQ}$ : The neglected navigating web of the incomprehensibly emerging and re-emerging Sarcoptes mite. Infect Genet Evol 2013, 17:253-259.

15. Gakuya F, Rossi L, Ombui J, Maingi N, Muchemi G, Ogara W, Soriguer RC, Alasaad S: The curse of the prey: Sarcoptes mite molecular analysis reveals potential prey-to-predator parasitic infestation in wild animals from Masai Mara, Kenya. Parasit Vectors 2011, 4:193.

16. Alasaad S, Oleaga A, Casais R, Rossi L, Molinar Min A, Soriguer RC, Gortazar C: Temporal stability in the genetic structure of Sarcoptes scabiei under the host-taxon law: empirical evidences from wildlife-derived Sarcoptes mite in Asturias, Spain. Parasit Vectors 2011, 4:151.

17. Alasaad S, Schuster RK, Gakuya F, Theneyan M, Jowers MJ, Maione S, Molinar Min A, Soriguer RC, Rossi L: Applicability of molecular markers to determine parasitic infection origins in the animal trade: a case study from Sarcoptes mites in wildebeest. Forensic Sci Med Pathol 2012, 8:280-284.

18. Walton SF, Holt DC, Currie BJ, Kemp DJ: Scabies: new future for a neglected disease. Adv Parasitol 2004, 57:309-376.

19. Pérez JM, Ruiz-Martínez I, Granados JE, Soriguer RC, Fandos P: The dynamics of sarcoptic mange in the ibex population of Sierra Nevada in Spain-influence of climatic factors. J Wildl Res 1997, 2:86-89.

20. Alasaad S, Soglia D, Sarasa M, Soriguer RC, Pérez JM, Granados JE, Rasero R, Zhu XQ, Rossi L: Skin-scale genetic structure of Sarcoptes scabiei populations from individual hosts: empirical evidence from Iberian ibexderived mites. Parasitol Res 2008, 104:101-105.

21. Alasaad S, Soglia D, Spalenza V, Maione S, Soriguer RC, Pérez JM, Rasero R, Ryser Degiorgis MP, Nimmervoll H, Zhu XQ, Rossi L: Is ITS-2 rDNA suitable marker for genetic characterization of Sarcoptes mites from different wild animals in different geographic areas? Vet Parasitol 2009, 159:181-185.

22. Pérez JM, Granados JE, Sarasa M, Serrano E: Usefulness of estimated surface area of damaged skin as a proxy of mite load in the monitoring of sarcoptic mange in free-ranging populations of Iberian wild goat; Capra pyrenaica. Vet Parasitol 2011, 176:258-264.
23. León-Vizcaíno L, Ruiz de Ybáñez MR, Cubero MJ, Ortiz JM, Espinosa J, Pérez $\mathrm{L}$, de Simón MA, Alonso F: Sarcoptic mange in Spanish ibex from Spain. J Wildl Dis 1999, 35:647-659.

24. Gakuya F, Ombui J, Maingi N, Muchemi G, Ogara W, Soriguer RC, Alasaad S: Sarcoptic mange and cheetah conservation in Masai Mara (Kenya): epidemiological study in a wildlife/livestock system. Parasitology 2012, 139:1587-1595.

doi:10.1186/1756-3305-6-242

Cite this article as: Alasaad et al:: The use of radio-collars for monitoring wildlife diseases: a case study from Iberian ibex affected by Sarcoptes scabiei in Sierra Nevada, Spain. Parasites \& Vectors 2013 6:242.

\section{Submit your next manuscript to BioMed Central and take full advantage of:}

- Convenient online submission

- Thorough peer review

- No space constraints or color figure charges

- Immediate publication on acceptance

- Inclusion in PubMed, CAS, Scopus and Google Scholar

- Research which is freely available for redistribution

Submit your manuscript at www.biomedcentral.com/submit
C BioMed Central 